\title{
Front Matter: Volume 9349
}

, "Front Matter: Volume 9349," Proc. SPIE 9349, Vertical External Cavity Surface Emitting Lasers (VECSELs) V, 934901 (17 March 2015); doi: $10.1117 / 12.2191384$

SPIE. Event: SPIE LASE, 2015, San Francisco, California, United States 


\section{PROCEEDINGS OF SPIE}

\section{Vertical External Cavity Surface Emitting Lasers (VECSELs) $\mathrm{V}$}

\section{Mircea Guina}

Editor

9-10 February 2015

San Francisco, California, United States

Sponsored by

SPIE

Cosponsored by

Coherent, Inc. (United States)

Published by

SPIE 
The papers included in this volume were part of the technical conference cited on the cover and title page. Papers were selected and subject to review by the editors and conference program committee. Some conference presentations may not be available for publication. The papers published in these proceedings reflect the work and thoughts of the authors and are published herein as submitted. The publisher is not responsible for the validity of the information or for any outcomes resulting from reliance thereon.

Please use the following format to cite material from this book:

Author(s), "Title of Paper," in Vertical External Cavity Surface Emitting Lasers (VECSELS) V, edited by Mircea Guina, Proceedings of SPIE Vol. 9349 (SPIE, Bellingham, WA, 2015) Article CID Number.

ISSN: 0277-786X

ISBN: 9781628414394

Published by

SPIE

P.O. Box 10, Bellingham, Washington 98227-0010 USA

Telephone +1 3606763290 (Pacific Time) · Fax +1 3606471445

SPIE.org

Copyright (C) 2015, Society of Photo-Optical Instrumentation Engineers.

Copying of material in this book for internal or personal use, or for the internal or personal use of specific clients, beyond the fair use provisions granted by the U.S. Copyright Law is authorized by SPIE subject to payment of copying fees. The Transactional Reporting Service base fee for this volume is $\$ 18.00$ per article (or portion thereof), which should be paid directly to the Copyright Clearance Center (CCC), 222 Rosewood Drive, Danvers, MA 01923. Payment may also be made electronically through CCC Online at copyright.com. Other copying for republication, resale, advertising or promotion, or any form of systematic or multiple reproduction of any material in this book is prohibited except with permission in writing from the publisher. The CCC fee code is 0277-786X/15/\$18.00.

Printed in the United States of America.

Publication of record for individual papers is online in the SPIE Digital Library.

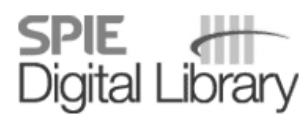

SPIEDigitalLibrary.org

Paper Numbering: Proceedings of SPIE follow an e-First publication model, with papers published first online and then in print. Papers are published as they are submitted and meet publication criteria. A unique citation identifier (CID) number is assigned to each article at the time of the first publication. Utilization of CIDs allows articles to be fully citable as soon as they are published online, and connects the same identifier to all online, print, and electronic versions of the publication. SPIE uses a six-digit CID article numbering system in which:

- The first four digits correspond to the SPIE volume number.

- The last two digits indicate publication order within the volume using a Base 36 numbering

system employing both numerals and letters. These two-number sets start with 00, 01, 02, 03, 04, $05,06,07,08,09,0 A, 0 B \ldots 0 Z$, followed by 10-1Z, 20-2Z, etc.

The CID Number appears on each page of the manuscript. The complete citation is used on the first page, and an abbreviated version on subsequent pages. 


\title{
Contents
}

\author{
$\checkmark$ Authors \\ vii Conference Committee
}

\section{SESSION 1 FUNDAMENTAL PHYSICS AND NEW CONCEPTS}

934902 Ultrafast non-equilibrium carrier dynamics in semiconductor laser mode-locking (Invited Paper) [9349-1]

934903 Influence of non-equilibrium carrier dynamics on pulse amplification in semiconductor gain media [9349-2]

934904 Pumping of VECSELs using high quantum defect and broadband sources (Invited Paper) [9349-3]

934905 DBR-free optically pumped semiconductor disk lasers (Invited Paper) [9349-4]

934906 Recent advances in the field of vertical-external-cavity surface-emitting lasers (Invited Paper) [9349-5]

\section{SESSION 2 POWER SCALING}

934907 Recent progress in wafer-fused VECSELs emitting in the 1310nm waveband (Invited Paper) [9349-6]

934908 Towards high power flip-chip long-wavelength semiconductor disk lasers (Invited Paper) [9349-7]

$934909>8 W$ GalnNAs VECSEL emitting at $615 \mathrm{~nm}[9349-8]$

\section{SESSION 3 WAVELENGTH EXTENSION}

9349 OC Degradation studies and pump optimization of optically pumped red-emitting AIGaInP-VECSELs [9349-11]

9349 OD Monolithic GalnNAsSb/GaAs VECSEL emitting at $1550 \mathrm{~nm}$ [9349-12]

9349 OE Power and wavelength scaling using semiconductor disk laser-bismuth fiber MOPA systems [9349-13] 
9349 OF Carrier-envelope-offset frequency detection of an ultrafast VECSEL (Invited Paper) [9349-14]

9349 OG Quantum dot based mode-locked AIGaInP-VECSEL [9349-15]

$9349 \mathrm{OH} \quad$ Ultrafast in-situ probing of passively mode-locked VECSEL dynamics [9349-16]

9349 ol Spectrally resolved pulse evolution in a mode-locked vertical-external-cavity surface-emitting laser from lasing onset measurements [9349-17]

\section{SESSION 5 INDUSTRY DEVELOPMENTS}

9349 OK Development and commercialization of mode-locked VECSELs (Invited Paper) [9349-19]

$9349 \mathrm{OL} \quad$ Latest achievements of NECSEL visible extended cavity surface emitting lasers (Invited Paper) [9349-20]

9349 OM $\quad 21.2 \%$ wall-plug efficiency green laser based on an electrically pumped VECSEL through intracavity second harmonic generation [9349-21]

9349 ON Simultaneous power and beam-shape optimization of an OPSL resonator (Invited Paper) [9349-22]

\section{SESSION 6 APPLICATIONS/MULTIFREQUENCY}

9349 OP Optically pumped semiconductor lasers for atomic and molecular physics (Invited Paper) [9349-24]

$93490 Q \quad$ Dual-comb MIXSEL [9349-25]

9349 OR Coherent spectral broadening and compression of the output of a mode-locked VECSEL (Best Student Paper Award) [9349-26]

POSTER SESSION

9349 OS Evaluation of the noise properties of a dual-frequency VECSEL for compact Cs atomic clocks [9349-27]

9349 ОT Optimisation of fundamental transverse mode output in electrically pumped vertical external cavity surface emitting lasers [9349-28]

9349 OU 1180nm VECSEL with 50 W output power [9349-29] 


\title{
Authors
}

Numbers in the index correspond to the last two digits of the six-digit citation identifier (CID) article numbering system used in Proceedings of SPIE. The first four digits reflect the volume number. Base 36 numbering is employed for the last two digits and indicates the order of articles within the volume. Numbers start with 00, 01, 02, 03, 04, 05, 06, 07, 08, 09, OA, OB...0Z, followed by 10-1Z, 20-2Z, etc.

\author{
Al Nakdali, Dalia, 06 \\ Albrecht, Alexander R., 05 \\ Babazadeh, Nasser, OT \\ Baili, G., OS \\ Baker, Caleb W., $\mathrm{OH}$ \\ Baumgärtner, Stefan, OC \\ Beaudoin, G., OS \\ Bek, Roman, OC, OG \\ Bialkowski, Bartlomiej, OK \\ Böttge, C. N., 02, 03 \\ Brauch, Uwe, OC \\ Brecher, Christian, ON \\ Burd, S., OP \\ Caliman, A., 07 \\ Camargo, F. A., OS \\ Cederberg, Jeffrey G., 05 \\ Chen, Tong, OM \\ Chen-Sverre, Theo, 이 \\ Childs, David T. D., OT \\ Danet, J.-M., OS \\ Dianov, Evgeny M., OE \\ Dolfi, D., OS \\ Dumont, P., OS \\ Emaury, F., OF \\ Fedorova, Ksenia A., 06 \\ Field, Simon, OL \\ Finander, Michael, OL \\ Gaafar, Mahmoud, 06 \\ Gao, Peng, OM \\ Garlich, Torsten, ON \\ Gbele, Kokou, $\mathrm{OH}$ \\ Georges, P., OS \\ Ghosh, Chuni, OM \\ Gini, E., OF \\ Golling, M., OF, OQ \\ Gozhyk, I., OS \\ Graf, Thomas, OC \\ Guerandel, S., OS \\ Guina, Mircea, 09, 0D, OU \\ Gumenyuk, Regina, OE \\ Haag, Sebastian, ON \\ Hader, J., 02, 03 \\ Hamilton, Craig J., OK \\ Head, C. Robin, 01 \\ Heikkinen, JuUso, 08, 0E \\ Hempler, Nils, OK \\ Hogg, Richard A., OT \\ Holleville, D., OS \\ Hooper, L. E., OR
}

\author{
lakovlev, V., 07 \\ Ivanov, Pavlo, OT \\ Jäger, Maren, $0 \mathrm{C}$ \\ Jetter, Michael, OC, OG \\ Jin, Xiao, OT \\ Jones, R. Jason, $\mathrm{OH}$ \\ Kahle, Hermann, OC, OG \\ Kantola, Emmi L., 09, OD, OU \\ Kapon, E., 07 \\ Keller, U., OF, OQ \\ Kersteen, Grizelda, OG \\ Kilen, I., 02, 03 \\ Klenner, A., OF, OQ \\ Koch, Martin, 06 \\ Koch, Stephan W., 02, 03, OH \\ Kontio, J., 08 \\ Korpijärvi, Ville-Markus, 09, 0D \\ Lahtonen, K., 08 \\ Leibfried, D., OP \\ Leinonen, Tomi, 09, OD, OE, OU \\ Link, S. M., OF, $0 Q$ \\ Lucas-Leclin, G., OS \\ Lyytikäinen, Jari, 07, 08, 0E \\ Mackenzie, William F., OL \\ Maker, Gareth T., OK \\ Malcolm, Graeme P. A., OK \\ Mangold, M., OF, OQ \\ Mateo, Cherry M. N., OC \\ Mayer, A. S., OF \\ Melkumov, Mikhail, OE \\ Mereuta, A., 07 \\ Michler, Peter, 0C, OG \\ Möller, Christoph, 06 \\ Moloney, Jerome $\mathrm{V} ., 02,03, \mathrm{OH}$ \\ Morvan, L., OS \\ Mosley, P. J., OR \\ Müller, Tobias, ON \\ Niven, Greg, OL \\ Okhotnikov, Oleg G., 07, 08, OE \\ Orchard, John, OT \\ Penttinen, Jussi-Pekka, 09, ou \\ Pillet, G., OS \\ Quarterman, A. H., 04, OR \\ Rafailov, Edik U., 06 \\ Rahimi-Iman, Arash, 06 \\ Ranta, Sanna, OU \\ Rantamäki, Antti, 07, 08, 0E \\ Saarinen, E., 08 \\ Sagnes, I., OS
}


Saraceno, C. J., OF

Saver, Sebastian, ON

Scheller, Maik, $\mathrm{OH}$

Schwarzbäck, Thomas, OC, OG

Seelert, Wolf, ON

Seurin, Jean-Francois, OM

Shakfa, Mohammad Khaled, 06

Shaw, Edward A., OI, OR

Sheik-Bahae, Mansoor, 05

Sirbu, A., 07

Stevens, Benjamin J., OT

Stolz, Wolfgang, 06

Tavast, Miki, OU

Tilma, B. W., OF, OQ

Tropper, Anne C., Ol

Turnbull, Andrew P., Ol

Valden, M., 08

van Leeuwen, Robert, $0 M$

Volet, N., 07

Wang, Qing, OM

Watkins, Laurence, OM

Weinspach, Karoline, $0 \mathrm{C}$

Wichmann, Matthias, 06

Wilcox, K. G., 04, OR

Wilson, A. C., OP

Wineland, D. J., OP

$X \cup$, Bing, $O M$

Xu, Guoyang, OM

Yang, Zhou, 05

Zaugg, C. A., OF, OQ

Zhang, Fan, 06

Zhao, Pu, OM

Zhou, Delai, OM

Zolotovskii, Igor, OE

Zontar, Daniel, ON

Proc. of SPIE Vol. $9349934901-6$ 


\section{Conference Committee}

Symposium Chairs

Guido Hennig, Daetwyler Graphics AG (Switzerland)

Yongfeng Lu, University of Nebraska-Lincoln (United States)

Symposium Co-chairs

Bo Gu, Bos Photonics (United States)

Andreas Tünnermann, Fraunhofer-Institut für Angewandte Optik und Feinmechanik (Germany) and Friedrich-Schiller-Universität Jena (Germany)

Program Track Chair

Klaus P. Streubel, OSRAM AG (Germany)

Conference Chair

Mircea Guina, Tampere University of Technology (Finland)

Conference Program Committee

Juan L. Chilla, Coherent, Inc. (United States)

Arnaud Garnache, Université Montpellier 2 (France)

Jennifer E. Hastie, University of Strathclyde (United Kingdom)

Elyahou Kapon, École Polytechnique Fédérale de Lausanne (Switzerland)

Ursula Keller, ETH Zürich (Switzerland)

Jerome V. Moloney, College of Optical Sciences, The University of Arizona (United States)

Anne C. Tropper, University of Southampton (United Kingdom)

Keith G. Wilcox, University of Dundee (United Kingdom)

Session Chairs

1 Fundamental Physics and New Concepts

Juan L. Chilla, Coherent, Inc. (United States)

2 Power Scaling

Jerome V. Moloney, College of Optical Sciences, The University of Arizona (United States) 
3 Wavelength Extension

Anne C. Tropper, University of Southampton (United Kingdom)

4 Mode-Locking

Keith G. Wilcox, University of Dundee (United Kingdom)

5 Industry Developments

Ursula Keller, ETH Zürich (Switzerland)

6 Applications/Multifrequency

David M. Stothard, Fraunhofer Center for Applied Photonics (United Kingdom) 